\title{
In vitro Methods to Study Antioxidant and Some Biological Activities of Essential Oils: a Review
}

\author{
Nesrine Benkhaira ${ }^{1}$ (D) , Saad ibnsouda Koraichi ${ }^{1}$ (D) , Kawtar Fikri-Benbrahim ${ }^{1, * \text { (D) }}$ \\ 1 Laboratory of Microbial Biotechnology and Bioactive Molecules, Sciences and Technologies Faculty, Sidi Mohamed Ben \\ Abdellah University, B.P. 2202 Imouzzer Road, Fez, Morocco; nesrine.benkhaira@usmba.ac.ma (N.B.); \\ saad.ibnsouda@usmba.ac.ma (S.I.K.); \\ * Correspondence: kawtar.fikribenbrahim@usmba.ac.ma (K.F.B.);
}

Scopus Author ID 55622411600

Received: 8.06.2021; Revised: 20.07.2021; Accepted: 24.07.2021; Published: 8.08.2021

\begin{abstract}
As essential oils (EOs) represent a new source of efficient and safe agents for health nowadays, the present review brings together the in vitro methods widely used to evaluate the antioxidant and some biological activities especially, antidiabetic, anticancer, antimicrobial, and antiinflammatory activities of EOs, in order to valorize these EOs and to highlight their potential benefits. Moreover, each method cited is along with its aim, principle, advantages and limitations, experimental protocols, and notes. Hence, this review will help researchers working on EOs, to save time while accessing this summary document on the one hand, and on the other hand, it will contribute to scientific approval of in vitro antioxidant and biological effects of EOs for future useful purposes.
\end{abstract}

Keywords: essential oils; bioactive molecules; in vitro methods; biological activities.

(C) 2021 by the authors. This article is an open-access article distributed under the terms and conditions of the Creative Commons Attribution (CC BY) license (https://creativecommons.org/licenses/by/4.0/).

\section{Introduction}

Currently, therapeutic drug failure (DTF) becomes a major public health challenge. This is due to the inefficiency of synthetic drugs, especially synthetic antioxidants [1,2], antibiotics [3], chemotherapeutic agents [4], anti-inflammatory, and antidiabetic drugs, which also cause serious side effects [5] such as liver and kidney toxicity, hypoglycemia, heart problems, and gastrointestinal reaction [6]; thus, an urgent need to develop new, better, and safer natural agents to fight against DTF[7].

Indeed, natural products are nowadays considered as a potential source for discovering new and efficient agents without side effects, especially EOs, from aromatic and medicinal plants[8-10]since they are used in healing therapies, in particular, aromatherapy [11]; a natural way to heal a person's body, mind, and soul through EOs [12,13].

Besides, EOs have a complex and variable composition resulting in many pharmacological properties[11,14,15], which allows them to be involved in the management of various diseases, such as cancer, microbial infections[16-18], diabetes, and chronic inflammation [19]. They can also combat oxidative stress [19], eventually leading to the abovementioned diseases and affecting food quality [20].

Therewith, it is necessary to target the right methods and techniques to evaluate the biological activities of EOs, whether in vitro or in vivo. Except that in vitro methods are simpler in their applications which makes them more feasible. They provide reliable results in a short time and avoid the use of animals [21]. 
In this context, this review aims to collect and describe in detail the most common in vitro techniques for evaluating antioxidant, antimicrobial, anti-inflammatory, antidiabetic, and anticancer properties of EOs. The present review could also serve as a guiding document for researchers working on EOs. This study reports for the first time the different in vitro techniques aimed at evaluating the biological activities of EOs.

\section{Evaluation of antioxidant activity}

\subsection{2,2-DPPH (2,2-diphenyl-1-picryl-hydrazyl-hydrate) assay.}

The DPPH test measures the ability of an antioxidant compound to act as a hydrogen donor or free radical scavenger. It is based on reducing the violet DPPH to stable pale yellow DPPH molecules in the presence of an antioxidant agent.

The DPPH test is simple, rapid, and reliable; however, it is sensitive to some Lewis bases and requires organic solvents and non-physiological radicals [22-25]. The DPPH test protocol is schematized below (Figure 1), according to the method described by Shimamura et al. [26].

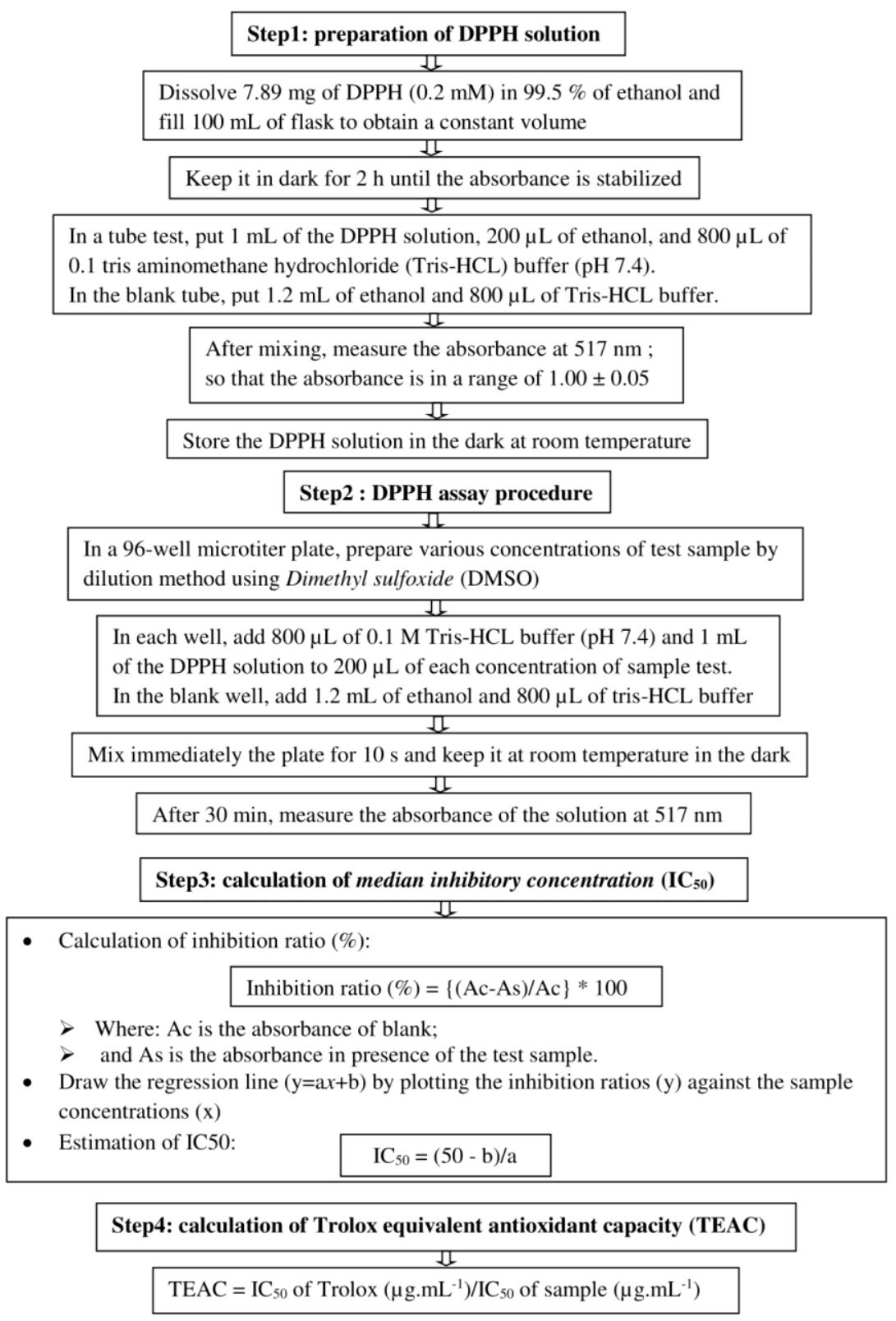

Figure 1. Experimental protocol of DPPH assay to assess the antioxidant activity of EOs. 
Note: The DPPH radical scavenging activity of the test sample is expressed as the TEAC. The higher TEAC means the higher DPPH radical scavenging activity. Trolox is used as positive control; its $\mathrm{IC}_{50}$ is determined by DPPH assay. The assay is repeated three times [26,27].

\subsection{ABTS (2,2'-azinobis-(3-ethylbenzthiazolin-6-sulfonic acid)) assay.}

The ABTS or TEAC assay measures the ability of an antioxidant to stabilize the ABTS radical cation $\left(\mathrm{ABTS}{ }^{+}\right.$) by an electron transfer mechanism. The ABTS ${ }^{+}$is a green-blue chromophore produced through a reaction between ABTS and potassium persulfate $\left(\mathrm{K}_{2} \mathrm{~S}_{2} \mathrm{O}_{8}\right)$. Indeed, the degree of discoloration is proportional to the ABTS ${ }^{+}$inhibition [29].

The ABTS assay is rapid, easy, and useful for both hydrophilic and lipophilic compounds. It can also be studied over a wide range of $\mathrm{pH}$ values. However, it is limited by the use of non-physiological radicals and the careful monitoring of time intervals $[13,29]$. The ABTS test protocol (Figure 2) is shown below, according to the method described by Kokina et al. [29] and Zhou et al. [30].

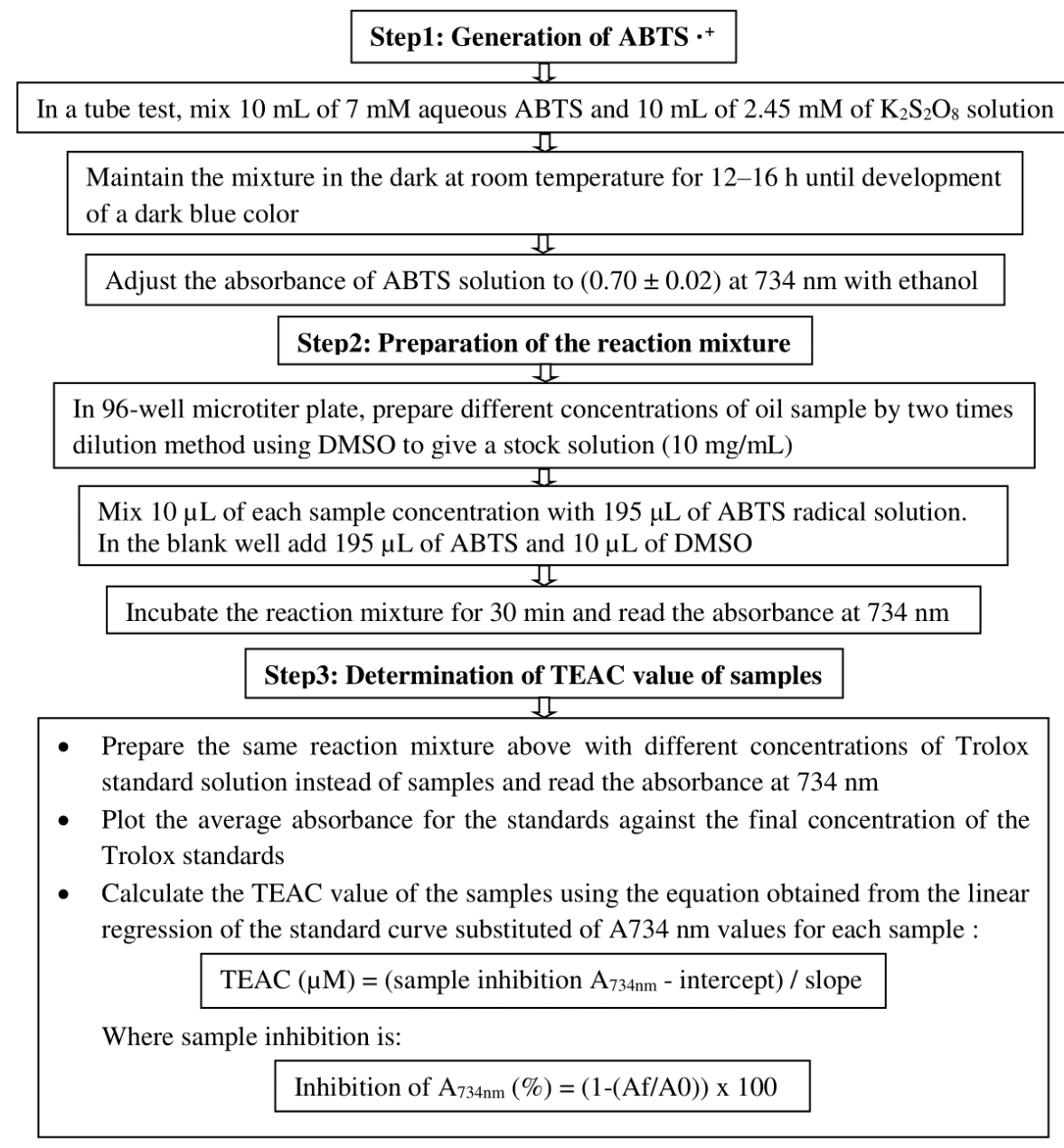

Figure 2. Experimental protocol of ABTS assay to assess the antioxidant activity of EOs.

Note: The ABTS $\cdot{ }^{+}$chromophore has three absorption maxima at wavelengths of 645,734 , and $815 \mathrm{~nm}$. Trolox is used as standard, and results are expressed in mmol Trolox equivalents per liter of EO. All measurements are performed in triplicate [29-30]. 


\subsection{FRAP (Ferric reducing antioxidant power) assay.}

The FRAP assay is based on the reduction of ferric tripyridyltriazine complex $\left(\mathrm{Fe}^{3+}-\right.$ TPTZ) to blue-colored ferrous tripyridyltriazine complex ( $\mathrm{Fe}^{2+}$-TPTZ) at low $\mathrm{pH}$ through electron-donating antioxidants [31].

The FRAP assay is simple, inexpensive, fast, and reproducible. Despite that, this assay is carried at non-physiological $\mathrm{pH}$ and does not measure all groups containing antioxidants, such as the sulfhydryl group; thus, it cannot necessarily reflect the entire antioxidant activity of a test sample [25]. Below, the FRAP test protocol (Figure 3) described by Benzie \& Strain [32] and modified by Pulido et al. [33].

Step 1: Preparation of FRAP reagent

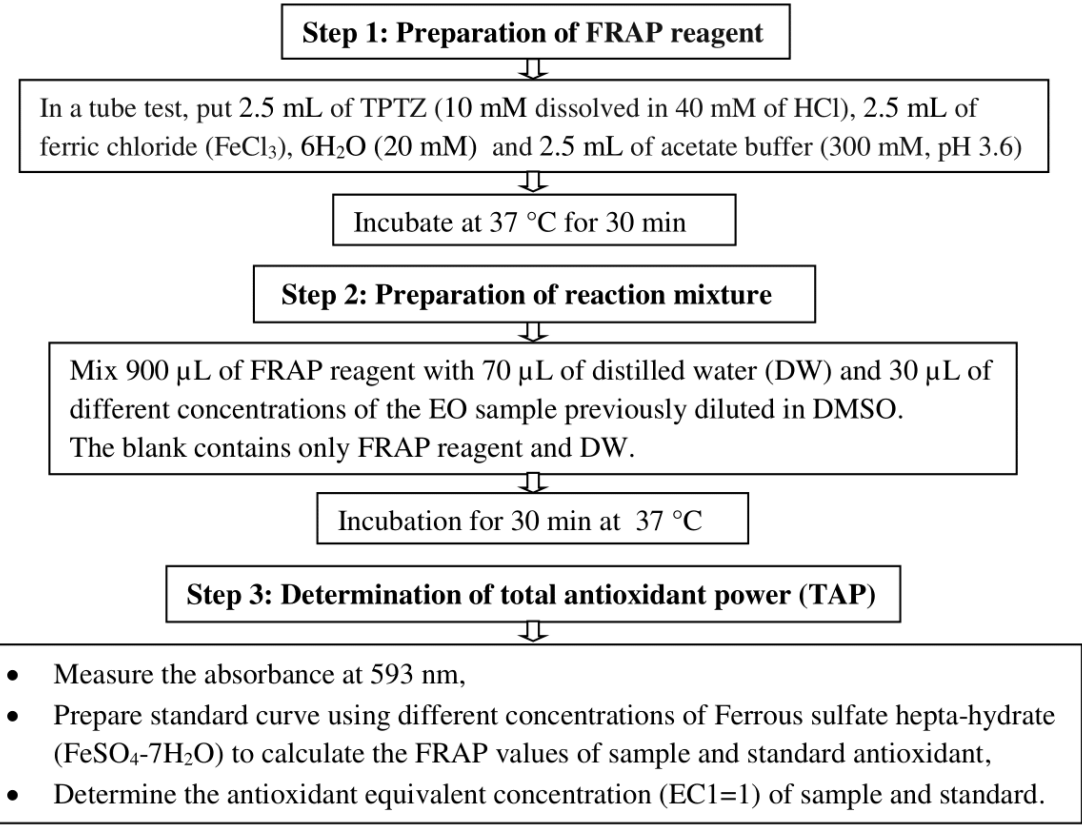

Figure 3. Experimental protocol of FRAP assay to assess the antioxidant activity of EOs.

Note: EC1 means the concentration of the antioxidant having a ferric reducing power equivalent to that of $1 \mathrm{mM}$ of $\mathrm{FeSO}_{4}-7 \mathrm{H}_{2} \mathrm{O}$, determined by the corresponding regression equation. The results are expressed in $\mu \mathrm{M}$ equivalent to $\mathrm{FeSO}_{4}-7 \mathrm{H}_{2} \mathrm{O}$ [34].

\section{Evaluation of anti-inflammatory activity}

\subsection{Nitric oxide (NO) production assay.}

The measurement of NO production is a method to assess the anti-inflammatory properties of EOs through measurement of the NO accumulation in a culture medium using the Griess reaction; thus, a low concentration of NO reveals an anti-inflammatory activity of the sample tested [35].

The NO production assay is greatly sensitive and reproducible with rapid analysis time. However, it is not suitable for monitoring NO in real-time. Moreover, careful control experiments must be performed to distinguish basal Nitrite $\left(\mathrm{NO}_{2}^{-}\right)$levels from those that arise from actual changes in NO concentration [36]. The assay protocol, according to Borges et al.[35], is described below (Figure 4). 


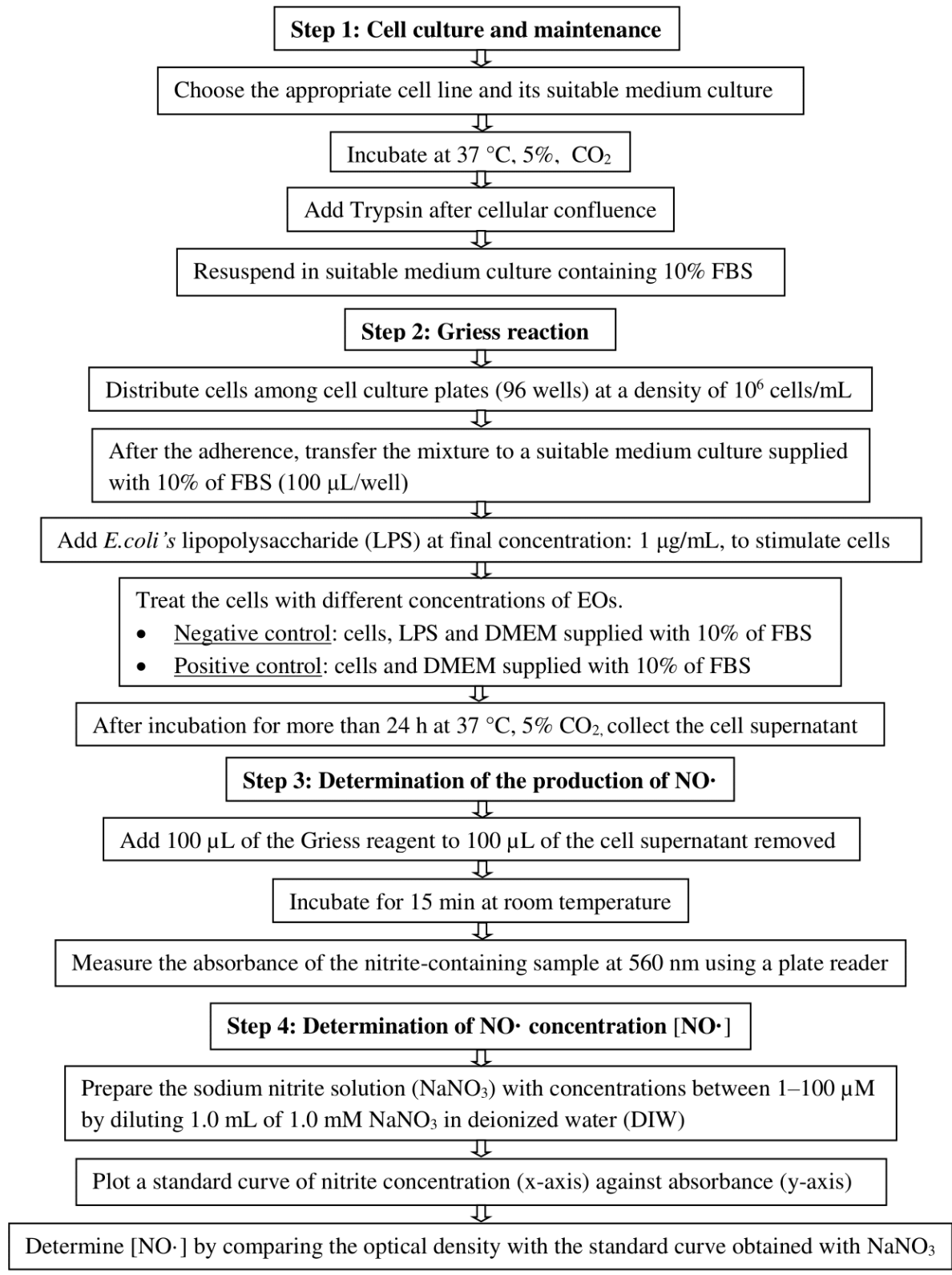

Figure 4. Experimental protocol of NO production assay to assess the anti-inflammatory activity of EOs.

Note: The cell lines widely used are Macrophages J774A1 and RAW 264.7 cells [35]. The DMEM represents the suitable culture medium containing the necessary nutrients and growth factors for cell lines. Griess reagent is prepared by mixing equal volumes of stock solutions of chloride-1-ethylenediamine $\left(\mathrm{C}_{12} \mathrm{H}_{16} \mathrm{Cl}_{2} \mathrm{Na}_{2}\right)$ dissolved at $0.1 \%$ in phosphoric acid $\left(\mathrm{H}_{3} \mathrm{PO}_{4}\right) 5 \%$ and sulfanilamide $\left(\mathrm{C}_{6} \mathrm{H}_{8} \mathrm{~N}_{2} \mathrm{O}_{2} \mathrm{~S}\right)$ dissolved at $1 \%$ in $\mathrm{H}_{3} \mathrm{PO}_{4}(5 \%)$. All experiments are performed in triplicate $[37,38]$.

\subsection{Cyclooxygenase (COX) inhibition assay.}

There are two isoforms of COX in mammals; a constitutive form (COX-1) and an inducible form (COX-2), which is responsible for the dramatic increase of prostaglandins (PGs) in pathological conditions [40-43]. Therefore, the inhibition of COX activity will prevent the conversion of AA to Prostaglandin H2 (PGH2), hence the inflammation prevention [44].

The prostaglandin E2 enzyme-linked immune-sorbent assay (PGE2 ELISA) is the most used test to detect COX inhibition as long as it is very sensitive, suitable for automation, and 
ideal for the rapid screening of wide chemical agents [43]. The only drawback is that the assay does not discriminate between the activities of different COX isoforms [45].

This assay is based on the competition between PGs and a PG-acetyl cholinesterase conjugate for a limited amount of PG antiserum [44]. Figure 5 summarizes the protocol described by Walker and Gierse [41] and Chandrakanthan et al. [45].

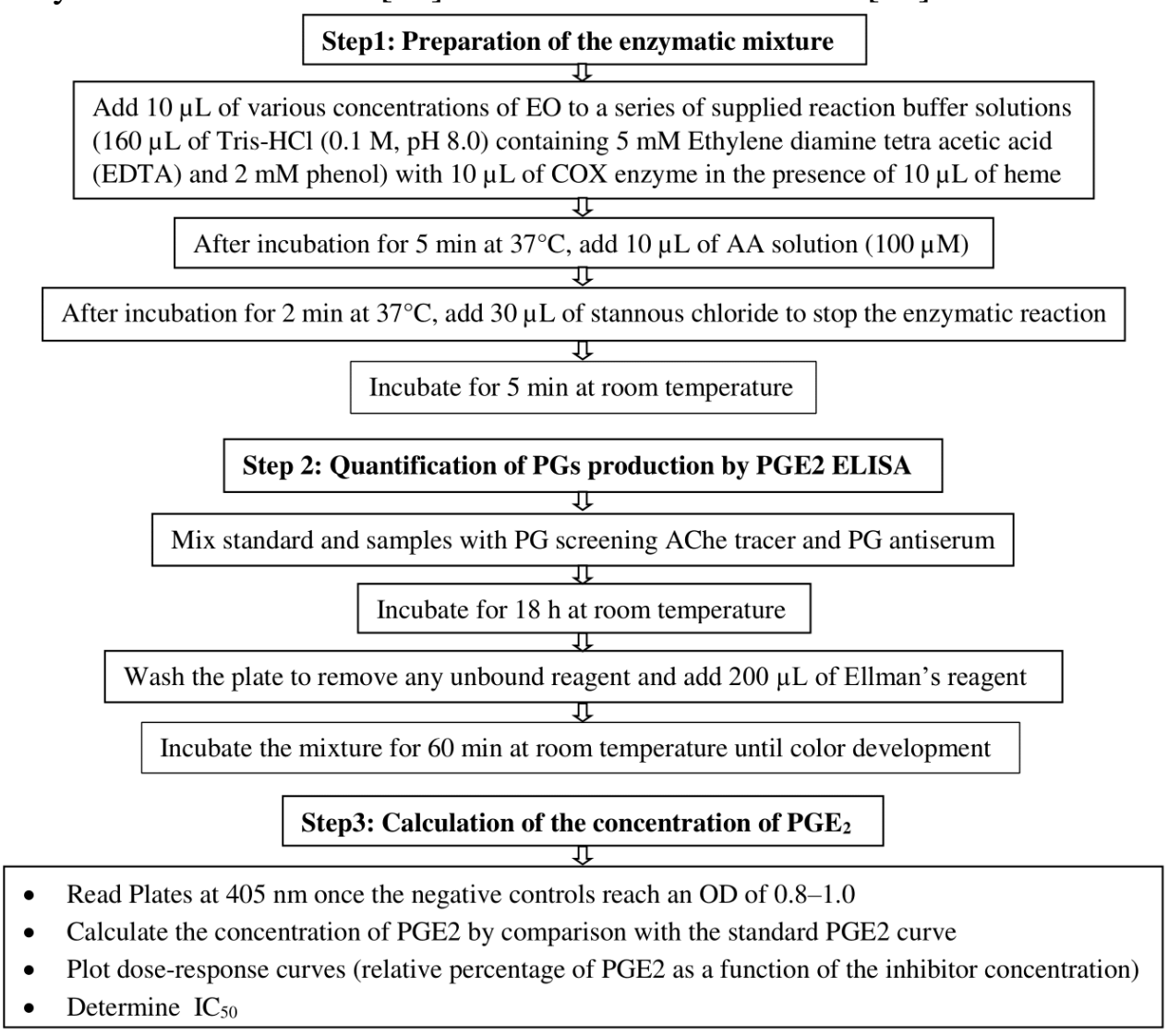

Figure 5. Experimental protocol of COX inhibition assay to assess the anti-inflammatory activity of EOs.

Note: The amount of PGE2 produced is expressed as a percentage relative to the positive and negative controls. The positive control contains DMSO without sample, and the negative control contains DMSO without AA [43].

\subsection{Lipoxygenase (LOX) inhibition assay.}

The LOX enzyme converts arachidonic acid or linoleic acid into various fatty acid metabolites involved in inflammation [47]. Therefore, the inhibition of LOX activity is important to prevent inflammatory diseases [48].

The spectrophotometric method is the most used to identify new LOX inhibitors since it is sensitive and rapid. Nevertheless, the reagents could rapidly oxidize, leading to an increasingly dark background. Also, the spectrophotometric readings must be precisely timed to quantify activity [47-49].

This assay is based on the enzymatic conversion of linoleic acid to conjugated dienes resulting in an increase in absorbance at $234 \mathrm{~nm}$. The test protocol used by Njenga and Viljoen [47] is summarized in the diagram below (Figure 6). 


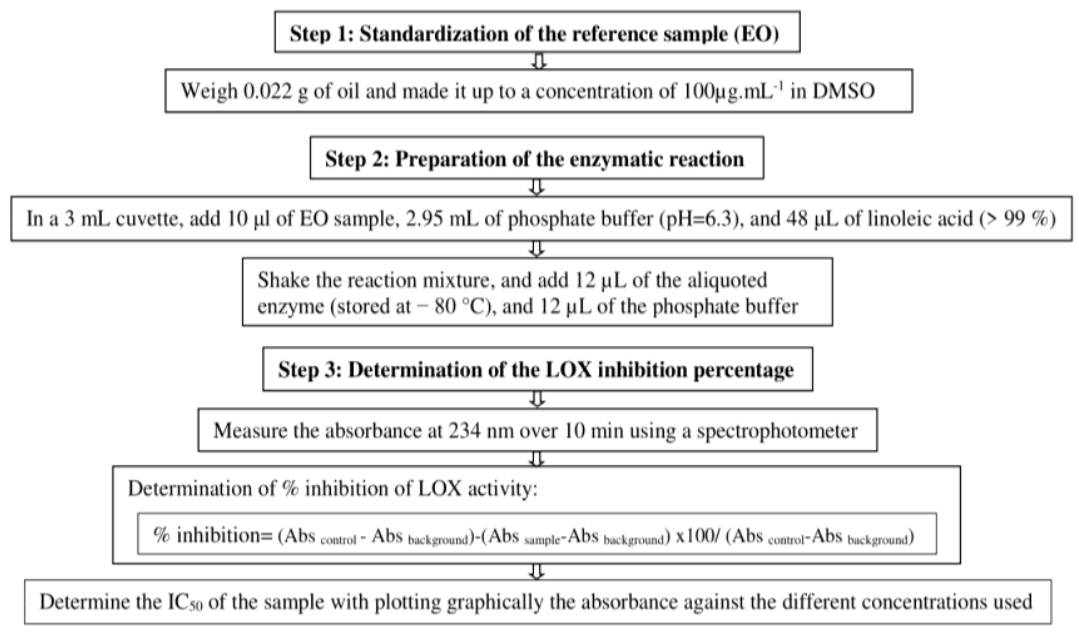

Figure 6. Experimental protocol of LOX inhibition assay to assess the anti-inflammatory activity of EOs.

Note: Nordihydroguaiaretic acid (NDGA) can be used as a positive control, while the DMSO can serve as a negative control (no enzyme inhibition). The test is performed in triplicate $[47,48]$.

\section{Evaluation of anticancer activity}

\subsection{MTT(3-(4,5-dimethylthiazol-2-yl)-2,5-diphenyltetrazolium bromide) assay.}

The MTT assay is used to assess the in vitro cytotoxic and antiproliferative activity of EOs. It is a colorimetric assay that measures the formazan product (dark purple) formed through the reduction of MTT (yellow dye) by active cells [50]. A high absorbance rate indicates an increase in cell proliferation and vice versa [51].

Although the MTT assay is rapid and economical, it has some limitations, such as the evaporation of volatile solvents and the instability of the formazan's signal. The MTT assay protocol described by Russo et al. [51] is presented below (Figure 7).

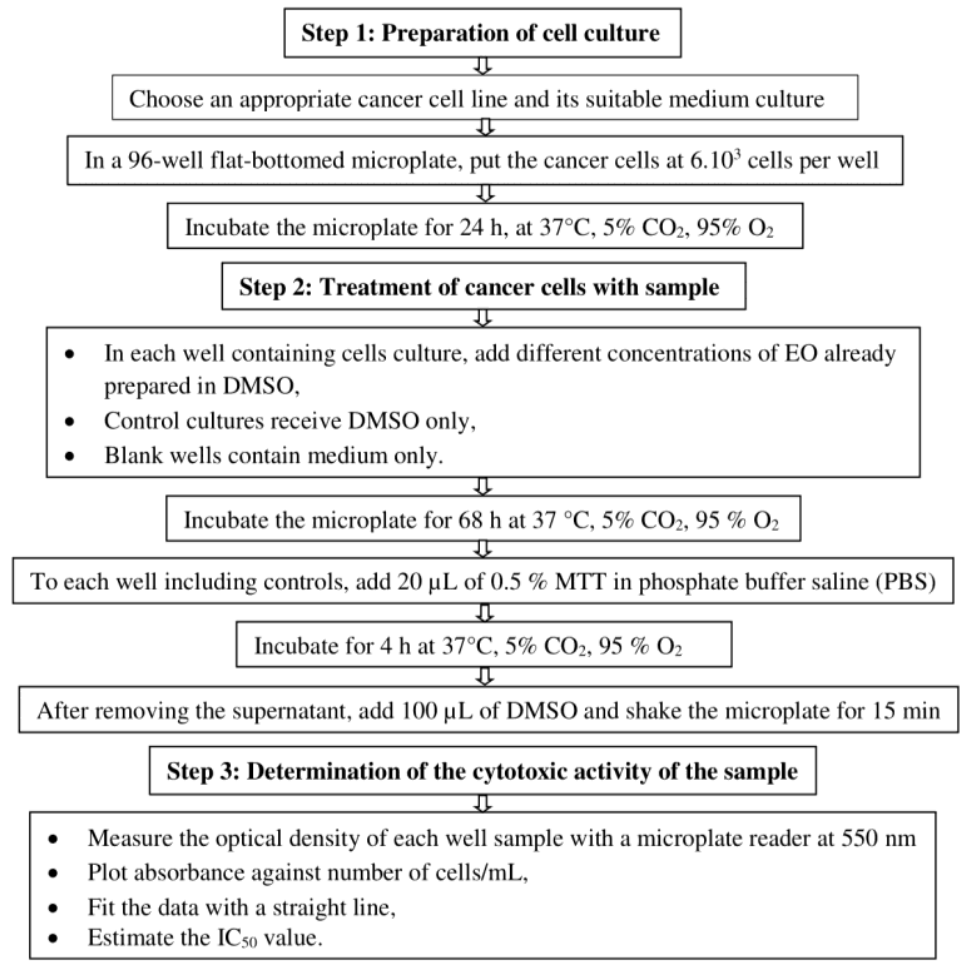

Figure 7. Experimental protocol of MTT assay for assessing EOs anticancer activity. 
Note: The cytotoxicity is expressed as IC50. Doxorubicin can be used as a positive control. The cell lines used in this protocol are from melanoma cancer: A375, M14, and A2085. Their respective suitable mediums are: DMEM supplemented with $10 \%$ fetal calf serum (FCS), 2.0 $\mathrm{mM}$ L-glutamine, $100 \mathrm{U} / \mathrm{mL}$ of penicillin, $100 \mu \mathrm{g} / \mathrm{mL}$ of streptomycin, and $25 \mu \mathrm{g} / \mathrm{mL}$ of fungizone; The Roswell Park Memorial Institute (RPMI) medium supplemented with 10\% FCS, $100 \mathrm{U} / \mathrm{mL}$ penicillin, $100 \mu \mathrm{g} / \mathrm{mL}$ streptomycin, $25 \mu \mathrm{g} / \mathrm{mL}$ fungizone, and DMEM supplemented with $10 \%$ FCS, $2.0 \mathrm{mM}$ L-glutamine, $100 \mathrm{U} / \mathrm{mL}$ penicillin, $100 \mu \mathrm{g} / \mathrm{mL}$ streptomycin, and $2 \mathrm{mM}$ of nonessential amino acids. The experiment is conducted in triplicate [52].

\subsection{Caspase-3 activity assay.}

Caspase-3 is an intracellular cysteine protease. Its activation is known to trigger apoptosis [53]. As caspase-3activity prevents tumorigenesis [54], it is necessary to test the in vitro effect of natural products on caspase-3of cancer cells. This assay is based on p-nitroaniline (pNa) monitoring, which is released during the cleavage of a caspase-specific peptide by the caspase-3. pNA can be quantified at $405 \mathrm{~nm}[53,58]$. This assay is a valuable, reliable, and time-saving technique for apoptotic studies. However, it is not quantitative; so, the resulting lysate cannot be used for downstream assays. Moreover, determining the appropriate timing to assay caspase activity can take some effort [55]. The diagram below (Figure 8) represents the protocol of caspase-3 activity assay described by Jamali et al. [57] and Szkoda [58].

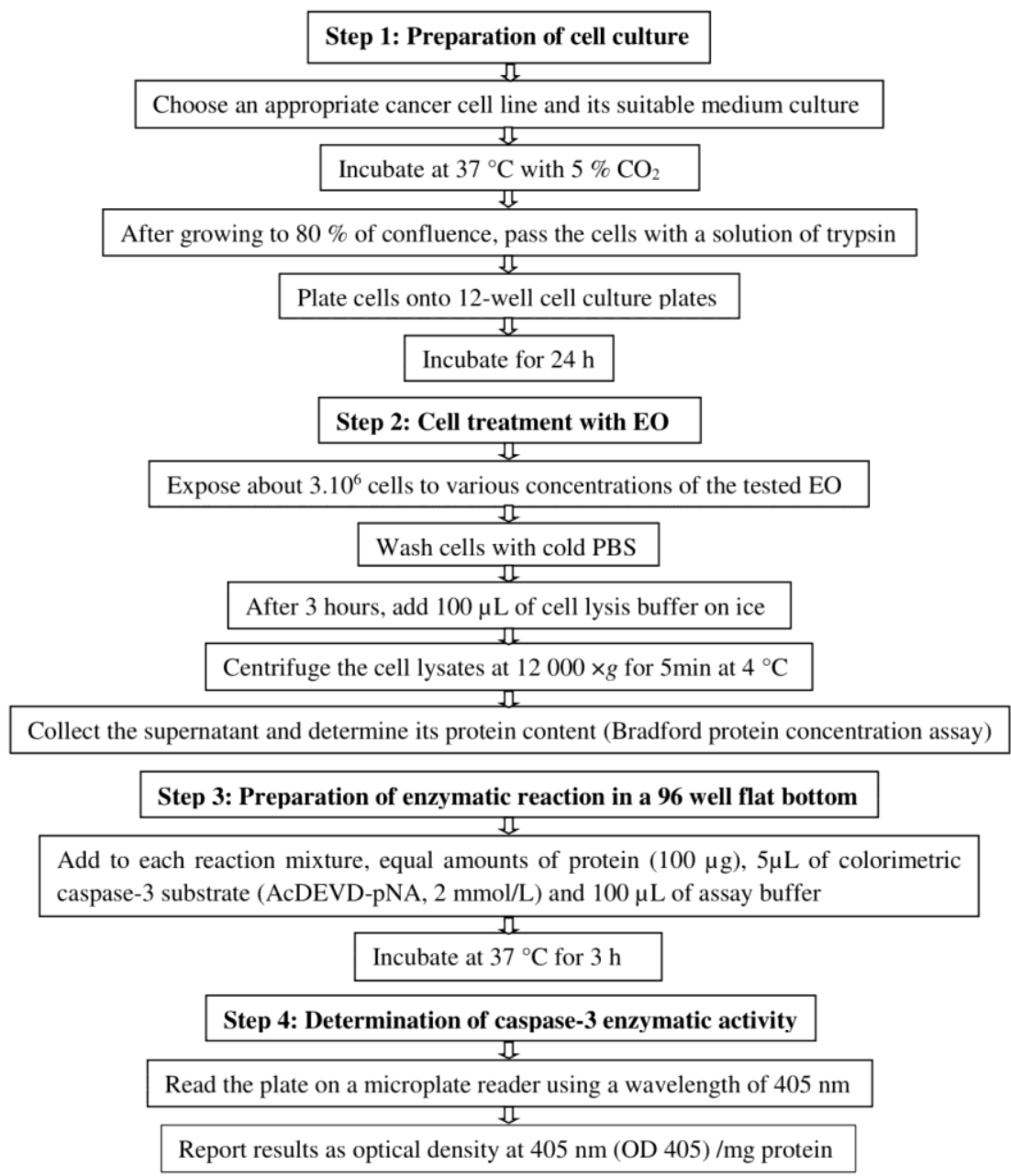

Figure 8. Experimental protocol of Caspase-3 activity assay to assess the anticancer activity of EOs. 
Note: The color reaction is directly proportional to the level of caspase enzymatic activity. Thymol and doxorubicin can be used as a positive control. The dithiothreitol (DTT), or EDTA can be used as assay buffers as well as cell lysis buffers. Among cancer cell lines used in this essay are M624 melanoma cells and human mammary carcinoma cell lines; MDA-MB-231, MCF-7. Their suitable media are respectively : DMEM supplemented with 10\% FBS and 1\% penicillin/streptomycin, and RPMI supplemented with $10 \% \mathrm{FBS}$ and $1 \%$ antibiotics $(100 \mathrm{U} / \mathrm{mL}$ penicillin and $100 \mu \mathrm{g} / \mathrm{mL}$ streptomycin) [56-58].

\section{Evaluation of antidiabetic activity}

\section{1. $\alpha$-amylase and $\alpha$-glucosidase inhibition assays.}

$\alpha$-amylase is a pancreatic enzyme that catalyzes the oligo and/or disaccharides into monosaccharides in the digestive system, while $\alpha$-glucosidase is an intestinal enzyme that hydrolyzes complex carbohydrates as starch to mere glucose molecules, which cause an increase in postprandial blood glucose levels $[59,60]$. Hence, the $\alpha$-amylase and $\alpha$-glucosidase inhibition present a significant way to reduce blood glucose levels in the case of diabetes $[61,62]$.

These assays are simple, reliable, and rapid; however, they require careful reagents preparation given their high sensitivity. Also, the turbidity resulting from enzymes' starch digestion may be a limitation of these tests [63]. Below, the test protocols of $\alpha$ amylase inhibition assay (Figure 9) and $\alpha$-glucosidase inhibition assay (Figure 10) described respectively by Bernfeld [64] and Oboh et al. [65].

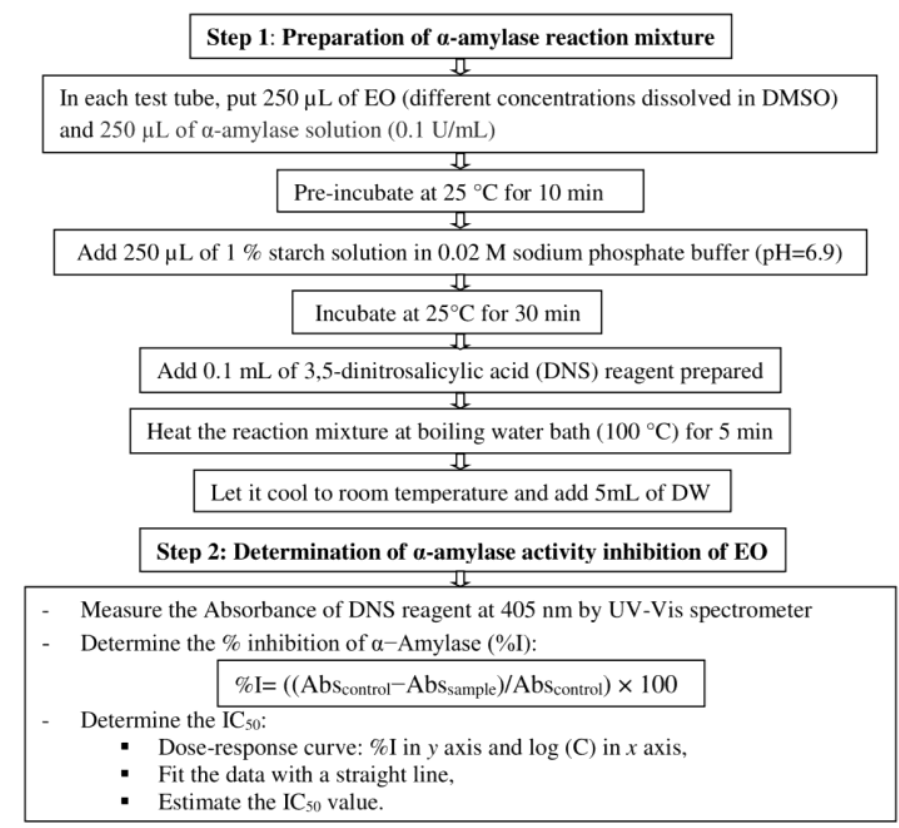

Figure 9. Experimental protocol of $\alpha$-amylase inhibition assay to assess the antidiabetic activity of EOs.

Note: $\alpha$-amylase inhibition is expressed as a decrease in units of reducing sugar (maltose equivalent) in $(\mu \mathrm{g} / \mathrm{mL})$. DNS is prepared by mixing $12 \mathrm{~g}$ of sodium potassium tartrate tetrahydrate in $8 \mathrm{~mL}$ of $2 \mathrm{M}$ sodium hydroxide $(\mathrm{NaOH})$, and $96 \mathrm{mM}$ DNS solution. The assay buffer is prepared by mixing $20 \mathrm{mM}$ Sodium phosphate buffer with $6.7 \mathrm{mM}$ Sodium chloride $(\mathrm{NaCl}),(\mathrm{pH}=6.9)$. Negative control contains DMSO and assay buffer instead of EO. The positive one contains acarbose instead of EO. The assay is carried out in triplicate $[64,66,67]$. 
Step 1: Preparation of $\alpha$-glucosidase reaction mixture

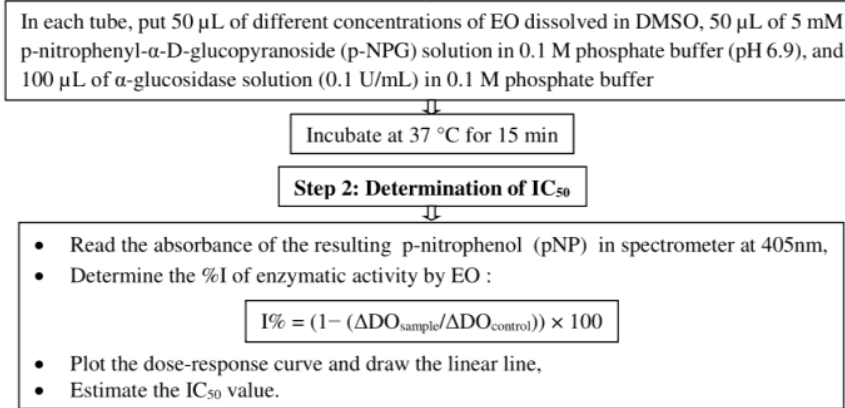

Figure 10. Experimental protocol of $\alpha$-glucosidase inhibition assay to assess the antidiabetic activity of EOs.

Note: The absorbance of the resulting p-NP is directly proportional to the enzyme activity and the test was performed in triplicate [68]. Negative control contains DMSO, substrate, and enzyme. While positive control contains acarbose instead of EO $[65,66]$.

\section{Evaluation of antimicrobial activity}

\subsection{Broth dilution method (BDM).}

The BDM is the most suitable in vitro test to determine antimicrobial agents' minimal inhibitory concentration (MIC). The MIC is the lowest concentration of an antimicrobial agent to inhibit the growth of a microorganism $[69,70]$. This method includes broth macro and micro dilutions [71].

The broth microdilution method is the most used since it is simple, economical, effective, and reproducible. Nevertheless, the method procedure must be carefully controlled to obtain reproducible results [72].

Figure 11 explains the experimental protocol of the broth microdilution method described by Balouiri et al. [73] and Nascente et al. [70] according to the clinical and laboratory standards institute (CLSI).

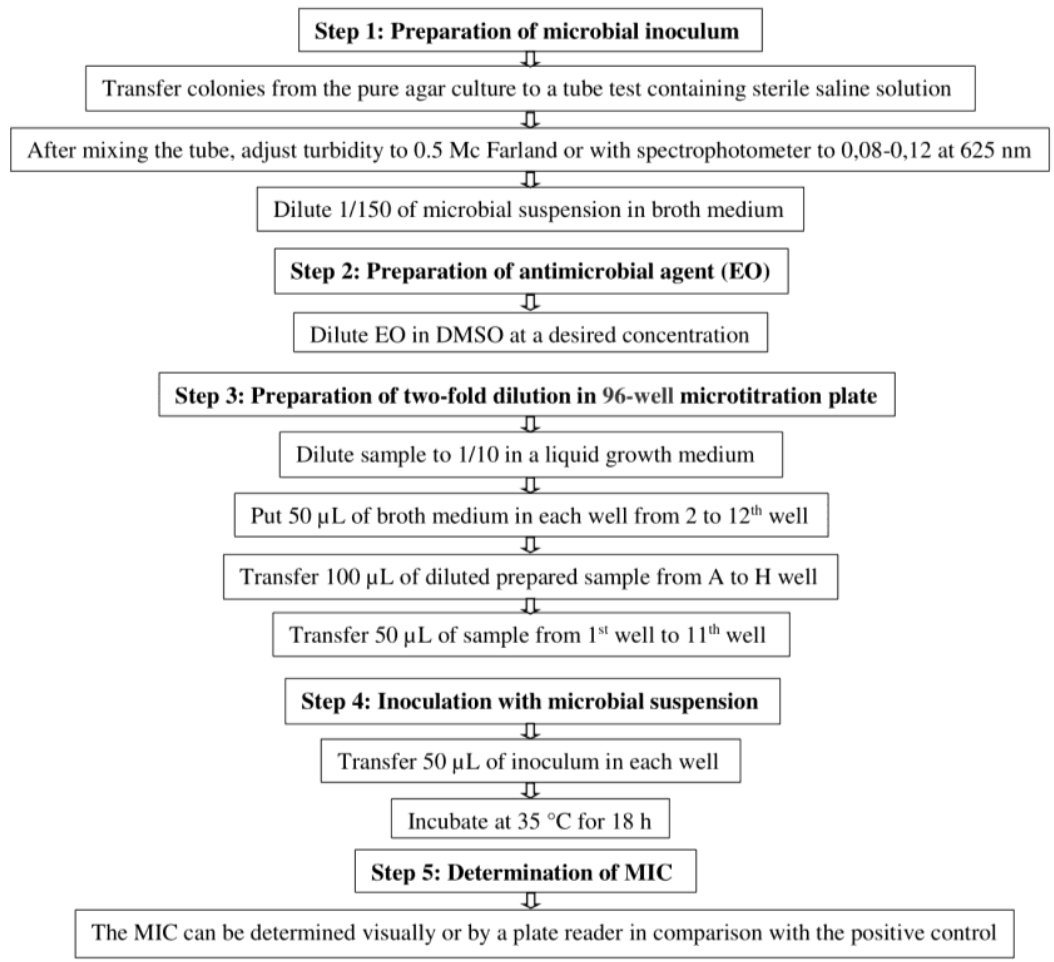

Figure 11. Experimental protocol of broth microdilution method to assess the antimicrobial activity of EOs. 
Note: This test requires Mueller Hinton broth (MHB) as a culture medium for bacteria and Yeast Extract Peptone Glycerol (YPG) for yeasts. The final inoculum sizes required for bacteria and yeasts are $5.10^{5} \mathrm{CFU} / \mathrm{mL}$ and $(0.5-2.5) \times 10^{3} \mathrm{CFU} / \mathrm{mL}$, respectively. Column 12 is reserved as a positive control of growth. The MIC is expressed in $\mu \mathrm{g} / \mathrm{mL}$ or $\mathrm{mg} / \mathrm{L}$. The BDM can also determine the minimum lethal concentration (MLC), defined as the lowest concentration killing $99.9 \%$ of the final microbial inoculum. The MLC is determined by subculturing the sample concentration (that does not show any microbial growth in wells) on the agar plate surface. Then, the number of surviving cells $(\mathrm{CFU} / \mathrm{mL})$ is counted after incubation for $24 \mathrm{~h}[71-73]$.

\subsection{Disc diffusion method (DDM).}

DDM or Kirby-Bauer method tests the sensitivity of certain pathogenic bacteria and yeasts to the tested antimicrobial agents [81]. In this method, the antimicrobial agent diffuses from the filter paper disk to the agar surface, which contains the test microorganism. If there is an antimicrobial activity, an inhibition zone (IZ) will be developed around the disk after incubation $[74,75]$.

The DDM is a simple, inexpensive, and standardized technique that tests enormous numbers of microorganisms and antimicrobial agents, with easy interpretation of the results provided. However, this method does not determine the MIC and cannot distinguish bactericidal and bacteriostatic effects. The recommended experimental protocol for the DDM (Figure 12), according to Singh et al. [76] is presented below.

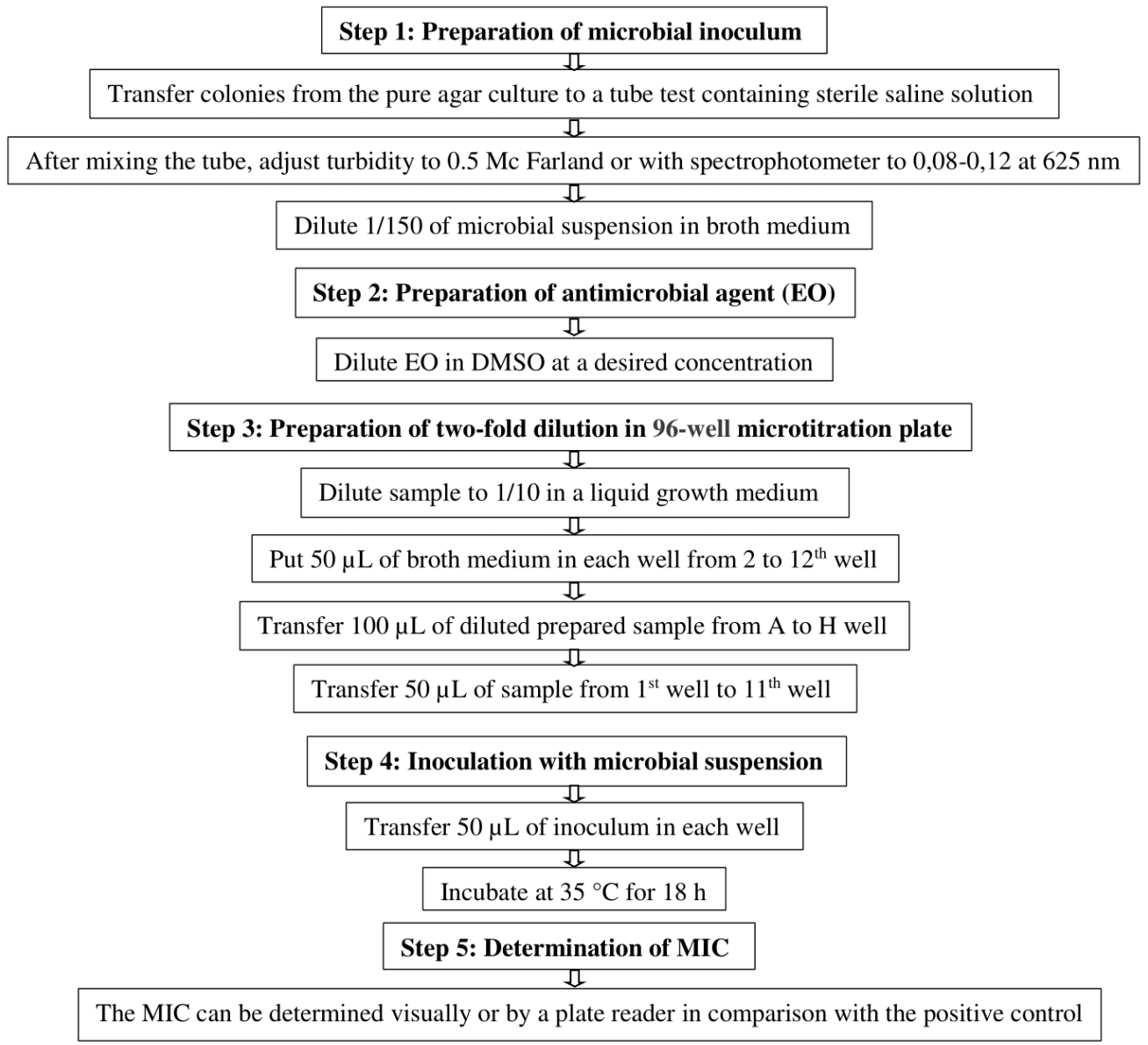

Figure 12. Experimental protocol of Disc Diffusion method to assess the antimicrobial activity of EOs. 
Note: Some antibiotics can be used as reference controls for the bacteria tested, such as ampicillin, chloramphenicol, and streptomycin at the desired concentration per disk. The culture medium used for the yeasts is MHA supplemented with $2 \%$ of glucose and $0.5 \mathrm{mg} / \mathrm{mL}$ of methylene blue. Regarding the incubation conditions, the temperature used for bacteria and yeast is $35^{\circ} \mathrm{C}$, and the incubation time required for bacteria is $16-18 \mathrm{~h}$ and for yeast is $20-24 \mathrm{~h}$. The final inoculum size is adjusted to 0.5 McFarland, corresponding to (1-2) $10^{8} \mathrm{CFU} / \mathrm{mL}$ for bacteria and (1-5) $10^{6} \mathrm{CFU} / \mathrm{mL}$ for yeasts [76-78].

\section{Conclusions}

The present review gathers the suitable in vitro methods to test antioxidant and some biological properties of EOs, particularly antidiabetic, antimicrobial, anticancer, and antiinflammatory activities to highlight their therapeutic potential and create a guiding document for researchers working on EOs. Indeed, the in vitro methods indicated are simple, fast, reproducible, sensitive, inexpensive, and avoid animals use. However, they have some common limitations, particularly the demand of high concentrations to avoid errors, the monitoring of time interval, volatility ad solubility of the used solvents, the risk of contamination, and repeat experiments. Ultimately, studies showed that EOs are excellent sources of bioactive natural compounds with many pharmacological and biological properties beneficial for health and the environment. Therefore, studying the EOs bioactivities, action modes, and bioactive molecules is necessary to detect new therapeutic properties and new efficient agents for application in the medical and pharmaceutical field. Besides, EOs could represent a source of biopesticides and biodetergents, contributing to protecting the environment; hence the interest in the scientific evaluation of their biological properties via in vitro and in vivo methods.

\section{Funding}

This research received no external funding.

\section{Acknowledgments}

This research has no acknowledgment.

\section{Conflicts of Interest}

The authors declare no conflicts of interest.

\section{References}

1. Jeong, S.-H.; Kim, B.-Y.; Kang, H.-G.; Ku, H.-O.; Cho, J.-H. Effects of butylated hydroxyanisole on the development and functions of reproductive system in rats. Toxicology 2005, 208, 49-62, https://doi.org/10.1016/j.tox.2004.11.014.

2. Bleve, M.; Ciurlia, L.; Erroi, E.; Lionetto, G.; Longo, L.; Rescio, L.; Schettino, T.; Vasapollo, G. An innovative method for the purification of anthocyanins from grape skin extracts by using liquid and subcritical carbon dioxide. Sep. Purif. Technol. 2008, 64, 192-197, https://doi.org/10.1016/j.seppur.2008.10.012.

3. Tariq, S.; Wani, S.; Rasool, W.; Shafi, K.; Ahmad, M.; Prabhakar, A.; Hussain, A.; Rather, M.A. Microbial Pathogenesis A comprehensive review of the antibacterial, antifungal and antiviral potential of essential oils and their chemical constituents against drug- resistant microbial pathogens. Microb. Pthogenes. 2019, 134, 103580, https://doi.org/10.1016/j.micpath.2019.103580.

4. Feng, S.S.; Chien, S. Chemotherapeutic engineering: Application and further development of chemical engineering principles for chemotherapy of cancer and other diseases. Chem. Eng. Sci. 2003, 58, 4087-4114, https://doi.org/10.1016/S0009-2509(03)00234-3. 
5. Adeghate, E.; Schattner, P.; Dunn, E. An update on the etiology and epidemiology of diabetes mellitus. Ann. N. Y. Acad. Sci. 2006, 1084, 1-29, https://doi.org/10.1196/annals.1372.029.

6. Nanjan, M.J.; Mohammed, M.; Prashantha Kumar, B.R.; Chandrasekar, M.J.N. Thiazolidinediones as antidiabetic agents: A critical review. Bioorg. Chem. 2018, 77, 548-567, https://doi.org/10.1016/j.bioorg.2018.02.009.

7. Diniz, L.R.L.; Bezerra Filho, C. da S.M.; Fielding, B.C.; De Sousa, D.P. Natural antioxidants: a review of studies on human and animal coronavirus. Oxid. Med. Cell. Longev. 2020, 2020, https://doi.org/10.1155/2020/3173281.

8. Zhang, D.; Gan, R.; Zhang, J.; Farha, A.K.; Li, H.; Zhu, F.; Wang, X.; Corke, H. Antivirulence properties and related mechanisms of spice essential oils: A comprehensive review. Compr. Rev. Food Sci. Food Saf. 2020, 19, 1018-1055, https://doi.org/10.1111/1541-4337.12549.

9. Benkhaira, N.; Koraichi, S.I.; Fikri-Benbrahim, K. Ethnobotanical survey on plants used by traditional healers to fight against COVID-19 in Fez city, Northern Morocco. Ethnobot. Res. Appl. 2021, 21, 1-18, https://dx.doi.org/10.32859/era.21.27.1-18.

10. Swamy, M.K.; Sinniah, U.R. Patchouli (Pogostemon cablin Benth.): Botany, agrotechnology and biotechnological aspects. Ind. Crops Prod. 2016, 87, 161-176, https://doi.org/10.1016/j.indcrop.2016.04.032.

11. Jugreet, B. S.; Suroowan, S.; Rengasamy, R.R.; Mahomoodally, M.F. Chemistry, bioactivities, mode of action and industrial applications of essential oils. Trends Food Sci. Technol. 2020, 101, 89-105, https://doi.org/10.1016/J.TIFS.2020.04.025.

12. Worwood, V.A. Aromatherapy for the Healthy Child: More Than 300 Natural, Nontoxic, and Fragrant Essential Oil Blends.New World Library 2000, https://www.amazon.com/Aromatherapy-Healthy-ChildNontoxic-Essential/dp/1577310950.

13. Ali, B.; Al-Wabel, N.A.; Shams, S.; Ahamad, A.; Khan, S.A.; Anwar, F. Essential oils used in aromatherapy: A systemic review. Asian Pac. J. Trop. Biomed. 2015, 5, 601-611, https://doi.org/10.1016/j.apjtb.2015.05.007.

14. Aumeeruddy-elalfi, Z.; Lall, N.; Fibrich, B.; Van Staden, A.B.; Hosenally, M. ; Mahomoodally, M.F. Selected essential oils inhibit key physiological enzymes and possess intracellular and extracellular antimelanogenic properties in vitro. J. Food Drug Anal. 2017, 26, 232-243, https://doi.org/10.1016/j.jfda.2017.03.002.

15. Dhifi, W.; Bellili, S.; Jazi, S.; Bahloul, N.; Mnif, W. Essential Oils' Chemical Characterization and Investigation of Some Biological Activities: A Critical Review. Medicines 2016, 3, 25, https://doi.org/10.3390/medicines3040025.

16. Freires, I.A.; Denny, C.; Benso, B.; De Alencar, S.M.; Rosalen, P.L. Antibacterial activity of essential oils and their isolated constituents against cariogenic bacteria: a systematic review. Molecules 2015, 20, 73297358, https://doi.org/doi:10.3390/molecules20047329.

17. Russo, R.; Corasaniti, M.T.; Bagetta, G.; Morrone, L.A. Exploitation of cytotoxicity of some essential oils for translation in cancer therapy. Evidence-Based Complement. Altern. Med. 2015, 2015, https://doi.org/10.1155/2015/397821.

18. El Hachlafi, N.; Chebat, A.; Bencheikh, R.S.; Fikri-Benbrahim, K. Ethnopharmacological study of medicinal plants used for chronic diseases treatment in Rabat-Sale-Kenitra region (Morocco). Ethnobot. Res. Appl. 2020, 20, 1-23, https://doi.org/10.32859/era.20.2.1-23.

19. Gutteridge, J.M.C.; Halliwell, B. Invited review free radicals in disease processes: a compilation of cause and consequence. Free Radic. Res. Commun. 1993, 19, 141-158, https://doi.org/10.3109/10715769309111598.

20. Wei, A.; Shibamoto, T. Antioxidant activities and volatile constituents of various essential oils. J. Agric. Food Chem. 2007, 55, 1737-1742,https://doi.org/10.1021/jf062959x.

21. Lourenço, S.C.; Moldão-Martins, M.; Alves, V.D. Antioxidants of natural plant origins: From sources to food industry applications. Molecules 2019, 24, 14-16, https://doi.org/10.3390/molecules24224132.

22. Wakefield, I.D.; Pollard, C.; Redfern, W.S.; Hammond, T.G.; Valentin, J.-P. The application of in vitro methods to safety pharmacology. Fundam. Clin. Pharmacol. 2002, 16, 209-218, https://doi.org/10.1046/j.1472-8206.2002.00099.x.

23. Garcia, E.J.; Cadorin Oldoni, T.L.; de Alencar, S.M.; Reis, A.; Loguercio, A.D.; Miranda Grande, R.H. Antioxidant activity by DPPH assay of potential solutions to be applied on bleached teeth. Braz. Dent. J. 2012, 23, 22-27, https://doi.org/10.1590/S0103-64402012000100004.

24. Sirivibulkovit, K.; Nouanthavong, S.; Sameenoi, Y. Paper-based DPPH assay for antioxidant activity analysis. Anal. Sci. 2018, 34, 795-800, https://doi.org/10.2116/analsci.18P014.

25. Singh, S.; Singh, R.P. In vitro methods of assay of antioxidants: an overview. Food Rev. Int. 2008, 24, 392415, https://doi.org/10.1080/87559120802304269.

26. Shimamura, T.; Sumikura, Y.; Yamazaki, T.; Tada, A.; Kashiwagi, T.; Ishikawa, H.; Matsui, T.; Sugimoto, N.; Akiyama, H.; Ukeda, H. Applicability of the DPPH assay for evaluating the antioxidant capacity of food additives - inter-laboratory evaluation study. Anal. Sci. 2014, 30, 717-721, https://doi.org/10.2116/analsci.30.717.

27. Adoni, M.; Yadam, M.; Gaddam, S.A.; Rayalacheruvu, U.; Kotakadi, V.S. Antimicrobial, Antioxidant, and Dye Degradation Properties of Biosynthesized Silver Nanoparticles From Artemisia Annua L. 2020, 10 (1), 
1981 - 1992, https://doi.org/10.33263/LIANBS101.19811992.

28. Manssouri, M.; Znini, M.; Majidi, L. Studies on the antioxidant activity of essential oil and various extracts of Ammodaucus leucotrichus Coss. \& Dur. Fruits from Morocco. J. Taibah Univ. Sci. 2020, 14, 124-130, https://doi.org/10.1080/16583655.2019.1710394.

29. Kokina, M.; Salevic, A.; Kaluševic, A.; Levic, S.; Pantic, M.; Dejan Pljevljakušic; Šavikin, K.; Shamtsyan, M.; Nikšic, M.; Nedovic, V. Characterization, antioxidant and antibacterial activity of essential oils and their encapsulation into biodegradable material followed by freeze drying. Food Technol. Biotechnol. 2019, 57, 282-289, https://doi.org/10.17113/ftb.57.02.19.5957.

30. Zhou, J.; Diao, X.; Wang, T.; Chen, G.; Lin, Q.; Yang, X.; Xu, J. Phylogenetic diversity and antioxidant activities of culturable fungal endophytes associated with the mangrove species Rhizophora stylosa and $R$. mucronata in the South China Sea. PLoS One 2018, 13, e0197359, https://doi.org/10.1371/journal.pone.0197359.

31. Benajiba, N.; Khojah, E. DPPH, FRAP and TAEC Assays with Postharvest Cabbage (Brassica oleracea) Parameters During the Packaging Process. Pak. J. Biol. Sci. 2021, 24, 182-187, https://doi.org/10.3923/pjbs.2021.182.187.

32. Benzie, I.F.F.; Strain, J.J. The ferric reducing ability of plasma (FRAP) as a measure of "antioxidant power": the FRAP assay. Anal. Biochem. 1996, 239, 70-76, https://doi.org/10.1006/abio.1996.0292.

33. Pulido, R.; Bravo, L.; Saura-Calixto, F. Antioxidant activity of dietary polyphenols as determined by a modified ferric reducing/antioxidant power assay. J. Agric. Food Chem. 2000, 48, 3396-3402, https://doi.org/10.1021/jf9913458.

34. Pirbalouti, A.G.; Setayesh, M.; Siahpoosh, A.; Mashayekhi, H. Antioxidant activity, total phenolic and flavonoids contents of three herbs used as condiments and additives in pickles products. Herba Pol. 2014, 59, 51-62, https://doi.org/10.2478/hepo-2013-0016.

35. Borges, R.S.; Keita, H.; Ortiz, B.L.S.; dos Santos Sampaio, T.I.; Ferreira, I.M.; Lima, E.S.; de Jesus Amazonas da Silva, M.; Fernandes, C.P.; de Faria Mota Oliveira, A.E.M.; da Conceição, E.C.; et al. Antiinflammatory activity of nanoemulsions of essential oil from Rosmarinus officinalis L.: in vitro and in zebrafish studies. Inflammopharmacology 2018, 26, 1057-1080, https://doi.org/10.1007/s10787-017-04389.

36. Hetrick, E.M.; Schoenfisch, M.H. Analytical chemistry of nitric oxide. Annu. Rev. Anal. Chem. 2009, 2, 409433, https://doi.org/10.1146/annurev-anchem-060908-155146.

37. Yang, Y.; Wei, Z.; Teichmann, A.T.; Wieland, F.H.; Wang, A.; Lei, X.; Zhu, Y.; Yin, J.; Fan, T.; Zhou, L. Development of a novel nitric oxide (NO) production inhibitor with potential therapeutic effect on chronic inflammation. Eur. J. Med. Chem. 2020, 193, 112216, https://doi.org/10.1016/j.ejmech.2020.112216.

38. Yang, E.J.; Kim, S.; Moon, J.Y.; Oh, T.H.; Baik, J.; Lee, N.; Hyun, C.G. Inhibitory effects of Fortunella japonica var. margarita and Citrus sunki essential oils on nitric oxide production and skin pathogens. Acta Microbiol. Immunol. Hung. 2010, 57, 15-27, https://doi.org/10.1556/AMicr.57.2010.1.2.

39. Tung, Y.T.; Yen, P.L.; Lin, C.Y.; Chang, S.T. Anti-inflammatory activities of essential oils and their constituents from different provenances of indigenous cinnamon (Cinnamomum osmophloeum) leaves. Pharm. Biol. 2010, 48, 1130-1136, https://doi.org/10.3109/13880200903527728.

40. Pan, B.S.; Kuo, Y.Y.; Chen, T.Y.; Liu, Y.C. Anti-oxidative and anti-inflammatory activities of two different species of a Chinese herb I-Tiao-Gung. Life Sci. 2005, 77, 2830-2839, https://doi.org/10.1016/j.lfs.2005.05.027.

41. Walker, M.C.; Gierse, J.K. In vitro assays for cyclooxygenase activity and inhibitor characterization. Methods Mol Biol. 2010, 644, 131-44, https://doi.org/10.1007/978-1-59745-364-6_11.

42. Jaradat, N.; Hawash, M.; Abualhasan, M.N.; Qadi, M.; Ghanim, M.; Massarwy, E.; Ammar, S.A.; Zmero, N.; Arar, M.; Hussein, F. Spectral characterization, antioxidant, antimicrobial, cytotoxic, and cyclooxygenase inhibitory activities of Aloysia citriodora essential oils collected from two Palestinian regions. BMC Complement. Med. Ther. 2021, 21, 1-11, https://doi.org/10.1186/s12906-021-03314-1.

43. Ayoub, S.S. In vitro Cyclooxygenase Activity Assay in Tissue Homogenates. In Cyclooxygenases; Springer, 2010, 117-120,https://doi.org/10.1007/978-1-59745-364-6_9.

44. Jaradat, N.; Al-lahham, S.; Abualhasan, M.N.; Bakri, A.; Zaide, H.; Hammad, J.; Hussein, F.; Issa, L.; Mousa, A.; Speih, R. Chemical Constituents, Antioxidant, Cyclooxygenase Inhibitor, and Cytotoxic Activities of Teucrium pruinosum Boiss. Essential Oil. Biomed Res Int. 2018, 2018, https://doi.org/10.1155/2018/4034689.

45. Chandrakanthan, M.; Handunnetti, S.M.; Premakumara, G.S.A.; Kathirgamanathar, S. Topical AntiInflammatory Activity of Essential Oils of Alpinia calcarata Rosc., Its Main Constituents, and Possible Mechanism of Action. Evidence-Based Complement. Altern. Med. 2020, 2020, https://doi.org/10.1155/2020/2035671.

46. Baylac, S.; Racine, P. Inhibition of 5-lipoxygenase by essential oils and other natural fragrant extracts. Int. J. Aromather. 2003, 13, 138-142, https://doi.org/10.1016/S0962-4562(03)00083-3.

47. Njenga, E.W.; Viljoen, A.M. In vitro 5-lipoxygenase inhibition and antioxidant activity of Eriocephalus L. (Asteraceae) species. South African J. Bot. 2006, 72, 637-641, https://doi.org/10.1016/j.sajb.2006.03.007.

48. Lončarić, M.; Strelec, I.; Moslavac, T.; Šubarić, D.; Pavić, V.; Molnar, M. Lipoxygenase Inhibition by Plant 
Extracts. Biomolecules 2021, 11, 152, https://doi.org/10.3390/biom11020152.

49. Waslidge, N.B.; Hayes, D.J. A colorimetric method for the determination of lipoxygenase activity suitable for use in a high throughput assay format. Anal. Biochem. 1995, 231, 354-358, https://doi.org/10.1006/abio.1995.0063.

50. Guo, R.; Liu, Q.; Wang, W.; Tayebee, R.; Mollania, F. Boron nitride nanostructures as effective adsorbents for melphalan anti-ovarian cancer drug. Preliminary MTT assay and In vitrocellular toxicity. J. Mol. Liq. 2021, 325, 114798, https://doi.org/10.1016/j.molliq.2020.114798.

51. Russo, A.; Formisano, C.; Rigano, D.; Senatore, F.; Delfine, S.; Cardile, V.; Rosselli, S.; Bruno, M. Chemical composition and anticancer activity of essential oils of Mediterranean sage (Salvia officinalis L.) grown in different environmental conditions. Food Chem. Toxicol. 2013, 55, 42-47, https://doi.org/10.1016/j.fct.2012.12.036.

52. Pisani, M.; Quassinti, L.; Bramucci, M.; Galassi, R.; Maggi, F.; Rossi, B.; Damin, A.; Carloni, P.; Astolfi, P. Nanostructured liquid crystalline particles as delivery vectors for isofuranodiene: Characterization and invitro anticancer activity. Colloids Surfaces B Biointerfaces 2020, 192, 111050, https://doi.org/10.1016/j.colsurfb.2020.111050.

53. Lavrik, I.N.; Golks, A.; Krammer, P.H. Caspases: pharmacological manipulation of cell death. J. Clin. Invest. 2005, 115, 2665-2672, https://doi.org/10.1172/JCI26252.

54. Olsson, M.; Zhivotovsky, B. Caspases and cancer. Cell Death Differ. 2011, 18, 1441-1449, https://doi.org/10.1038/cdd.2011.30.

55. Wu, R.A.; Ding, Q.; Lu, H.; Tan, H.; Sun, N.; Wang, K.; He, R.; Luo, L.; Ma, H.; Li, Z. Caspase 3-mediated cytotoxicity of mealworm larvae (Tenebrio molitor) oil extract against human hepatocellular carcinoma and $\begin{array}{llllll}\text { colorectal adenocarcinoma. } & J & \text { Ethnopharmacol. } & \mathbf{2 0 2 0}, & 250, & 112438 \text {, }\end{array}$ https://doi.org/10.1016/j.jep.2019.112438.

56. Butterick, T.A.; Duffy, C.M.; Lee, R.E.; Billington, C.J.; Kotz, C.M.; Nixon, J.P. Use of a caspase multiplexing assay to determine apoptosis in a hypothalamic cell model. Journal Vis. Exp. 2014, e51305, https://doi.org/10.3791/51305.

57. Jamali, T.; Kavoosi, G.; Safavi, M.; Ardestani, S.K. In-vitro evaluation of apoptotic effect of OEO and thymol in 2D and 3D cell cultures and the study of their interaction mode with DNA. Sci. Rep. 2018, 8, 1-19, https://doi.org/10.1038/s41598-018-34055-w.

58. Szkoda, B.E. The effects of citral on caspase-3 activation in M624 and HaCat cells. Electronic Thesis or Dissertation.Marietta College. 2016, https://doi.org/10.13140/RG.2.2.18374.06728.

59. Carpéné, C.; Les, F.; Cásedas, G.; Umuhoza, F.; Arbonés-Mainar, J.M.; López, V. Engineering and biomedical effects of commercial juices of berries, cherries, and pomegranates with high polyphenol content. In Non-Alcoholic Beverages 2019, 6,259-283, https://doi.org/10.1016/B978-0-12-815270-6.00009-8.

60. Majouli, K.; Besbes Hlila, M.; Hamdi, A.; Flamini, G.; Ben Jannet, H.; Kenani, A. Antioxidant activity and a-glucosidase inhibition by essential oils from Hertia cheirifolia (L.). Ind. Crops Prod. 2016, 82, 23-28, https://doi.org/10.1016/j.indcrop.2015.12.015.

61. Bhutkar, M.A.; Bhise, S.B. In vitroassay of alpha amylase inhibitory activity of some indigenous plants. Int. J. Chem. Sci. 2012, 10, 457-462, https://doi.org/10.31031/MAPP.2018.01.000518.

62. Unnikrishnan, P.S.; Suthindhiran, K.; Jayasri, M.A. Alpha-amylase Inhibition and Antioxidant Activity of Marine Green Algae and its Possible Role in Diabetes Management. Pharmacogn. Mag. 2015, 11, 511-515, https://doi.org/10.4103/0973-1296.172954.

63. Virolle, M.J.; Morris, V.J.; Bibb, M.J. A simple and reliable turbidimetric and kinetic assay for alpha-amylase that is readily applied to culture supernatants and cell extracts. J. Ind. Microbiol. 1990, 5, 295-301, https://doi.org/10.1007/BF01578204.

64. Bernfeld, P. Amylases, alpha and beta. Methods Enzymol. 1955, 1, 149-158, http://dx.doi.org/10.1016/00766879(55)01021-5.

65. Oboh, G.; Akinbola, I.A.; Ademosun, A.O.; Sanni, D.M.; Odubanjo, O. V.; Olasehinde, T.A.; Oyeleye, S.I. Essential Oil from Clove Bud (Eugenia aromatica Kuntze) Inhibit Key Enzymes Relevant to the management of type-2 diabetes and some pro-oxidant induced lipid peroxidation in rats pancreas in vitro. J. Oleo Sci. 2015, 64, 775-782, https://doi.org/10.5650/jos.ess14274.

66. Hichri, F.; Omri, A.; Hossan, A.S.M.; Ben Jannet, H. Alpha-glucosidase and amylase inhibitory effects of Eruca vesicaria subsp. longirostris essential oils: synthesis of new 1,2,4-triazole-thiol derivatives and 1,3,4thiadiazole with potential inhibitory activity. Pharm. Biol. 2019, 57, 564-570, https://doi.org/10.1080/13880209.2019.1642363.

67. Liu, S.; Yu, J.; Guo, S.; Fang, H.; Chang, X. Inhibition of pancreatic $\alpha$-amylase by Lonicera caerulea berry polyphenols in vitroand their potential as hyperglycemic agents. LWT 2020, 126, 109288, https://doi.org/10.1016/j.lwt.2020.109288.

68. Mugaranja, K.P.; Kulal, A. Alpha glucosidase inhibition activity of phenolic fraction from Simarouba glauca: An in-vitro, in-silico and kinetic study. Heliyon 2020, 6, e04392, https://doi.org/10.1016/j.heliyon.2020.e04392.

69. Wiegand, I.; Hilpert, K.; Hancock, R.E.W. Agar and broth dilution methods to determine the minimal inhibitory concentration (MIC) of antimicrobial substances. Nat. Protoc. 2008, 3, 163, 
https://doi.org/10.1038/nprot.2007.521.

70. Nascente, P. da S.; Meinerz, A.R.M.; de Faria, R.O.; Schuch, L.F.D.; Meireles, M.C.A.; de Mello, J.R.B. CLSI broth microdilution method for testing susceptibility of Malassezia pachydermatis to thiabendazole. Brazilian J. Microbiol. 2009, 40, 222-226, https://doi.org/10.1590/S1517-83822009000200002.

71. Bagheri, L.; Khodaei, N.; Salmieri, S.; Karboune, S.; Lacroix, M. Correlation between chemical composition and antimicrobial properties of essential oils against most common food pathogens and spoilers: in-vitro efficacy and predictive modelling. Microb. Pathog. 2020, 147, 104212, https://doi.org/10.1016/j.micpath.2020.104212.

72. Horváth, G.; Bencsik, T.; Ács, K.; Kocsis, B. Sensitivity of ESBL-producing gram-negative bacteria to essential oils, plant extracts, and their isolated compounds. Acad. Press. Amsterdam Antibiotic Resistance 2016, 239-269, https://doi.org/10.1016/B978-0-12-803642-6.00012-5.

73. Balouiri, M.; Sadiki, M.; Ibnsouda, S.K. Methods for in vitroevaluating antimicrobial activity: A review. $J$. Pharm. Anal. 2016, 6, 71-79,https://doi.org/10.1016/j.jpha.2015.11.005.

74. Christenson, J.C.; Korgenski, E.K. Laboratory Diagnosis of Infection Due to Bacteria, Fungi, Parasites, and Rickettsiae. In Principles and Practice of Pediatric Infectious Diseases: Fourth Edition; Elsevier Inc. 2008, 1341-1352, https://doi.org/10.1016/B978-0-7020-3468-8.50292-3.

75. Jonasson, E.; Matuschek, E.; Kahlmeter, G. The EUCAST rapid disc diffusion method for antimicrobial susceptibility testing directly from positive blood culture bottles. J. Antimicrob. Chemother. 2020, 75, 968978, https://doi.org/10.1093/jac/dkz548.

76. Singh, I.; Gupta, S.; Gautam, H.K.; Dhawan, G.; Kumar, P. Antimicrobial, radical scavenging, and dye degradation potential of nontoxic biogenic silver nanoparticles using Cassia fistula pods. Chem. Pap. 2021, 75, 979-991, https://doi.org/10.1007/s11696-020-01355-3.

77. Mith, H.; Dure, R.; Delcenserie, V.; Zhiri, A.; Daube, G.; Clinquart, A. Antimicrobial activities of commercial essential oils and their components against food-borne pathogens and food spoilage bacteria. Food Sci. Nutr.2014, 2, 403-416, https://doi.org/10.1002/fsn3.116.

78. Gore, V.A.; Tekale, S.U.; Bhale, S.P.; Rajani, D.P.; Domb, A.J.; Pawar, R.P. Synthesis and biological evaluation of novel thiazole hydrazines as antimicrobial and antimalarial agents. Lett. Appl. NanoBioScience 2021, 10, 1846-1855, https://doi.org/10.33263/LIANBS101.18461855. 